\title{
Examining the extent to which repeat and near repeat patterns can prevent crime
}

Spencer P. Chainey, University College London, Department of Security and Crime Science, 35 Tavistock Square, London, WC1H 9EZ, England. s.chainey@ucl.ac.uk

Sophie J. Curtis-Ham, New Zealand Police, Wellington, New Zealand. sophie.curtis-

ham@police.govt.nz

Gordon J. Burns, New Zealand Police, Wellington, New Zealand. Gordon.BURNS@police.govt.nz

R. Mark Evans, New Zealand Police, Wellington, New Zealand. Robert.Evans@police.govt.nz

Submitted version 2 December 2016

Published May 2018 in Policing: An International Journal

https://www.emeraldinsight.com/doi/abs/10.1108/PIJPSM-12-2016-0172

\footnotetext{
Abstract

Purpose: The paper examines the extent and variation in the estimates to which crime can be prevented using patterns of repeats and near repeats, and whether hotspot analysis complements these patterns.

Method: Crime data for four study areas in New Zealand are used to examine differences in the extent of burglary repeat and near repeat victimisation. Hotspots of burglary are also created to determine the extent to which burglary repeats and near repeats spatially intersect hotspots. Findings: The extent of repeats and near repeats vary, meaning there is variation in the estimated prevention benefits that repeat and near repeat patterns offer. In addition, at least half of the burglaries repeats and near repeats were not located within hotspots.

Research limitations: The use of other techniques for examining crime concentration could be used to improve the research observations.
} 
Practical implications: By showing that levels of repeats and near repeats vary, and the extent to which these observations coincide in hotspots offers practitioners a better means of determining whether repeat and near repeat patterns are reliable for informing crime prediction and crime prevention activities.

Originality/value: The paper is the first known research study that explicitly measures the variation in the extent of repeats and near repeats and the spatial intersection of these patterns within crime hotspots. The results suggest that rather than considering the use of repeat and near repeat patterns as a superior method for predicting and preventing crime, value remains in using hotspot analysis for determining where crime is likely to occur, particularly when hotspot analysis emphasises other locations for resource targeting. 


\section{Introduction}

The patterning principles of repeat victimisation and near repeat victimisation have been increasingly used in recent years to inform crime prevention practice. The analytical findings of repeat and near repeat victimisation, and the theoretical principles explaining these patterns, provide a more precise geographic and temporal observation of where and when crime may occur over traditional hotspot analysis (Johnson et al., 2008). The identification of repeat and near repeat patterns in the analysis of crime has subsequently led to police agencies designing tactics that have successfully countered the predictable patterns these repeat and near repeat observations inform (Forrester et al., 1988; Fielding and Jones, 2012), and have informed the design of several predictive policing software applications (Esri, 2016, IFMPT, 2016; PredPol, 2013).

Although the application of the patterning principles of repeat and near repeat victimisation has received significant interest, to date little research has been conducted that has explicitly examined the extent to which these patterns may vary between areas. Secondly, very little research has also been conducted that has examined the extent to which repeats and near repeats are collocated within crime hotspots. As the theoretical principles explaining the spatial and temporal patterns of repeats, near repeats and crime hotspots are different, and in turn inform different types of prevention programmes, an understanding of the variation of these repeats and near repeats and the extent to which these patterns spatially coincide with hotspots provides value for informing practice.

The research findings we present in this article have involved examining the extent to which repeat victimisation and near repeat victimisation of domestic burglary account for all domestic burglaries in four areas in New Zealand. The research focuses specifically on domestic burglary because of the use of the results for informing New Zealand Police's national burglary prevention strategy. The four areas in New Zealand that are examined are different in terms of their burglary rate and domestic housing infrastructure. We hypothesise that estimates of the extent of repeats and near repeats will vary between areas, and will therefore result in differences in the likely impact of crime prevention initiatives that aim to counter repeats and near repeats. The second part of the research examines the extent to which burglary repeats and near repeats are located within burglary hotspots. Previous 
commentators have suggested that repeat victimisation is closely associated with hotspots (Bennett, 1995; Johnson et al. 1997; Townsley et al. 2000; Weisel, 2005) but few results exist on the extent to which both repeats and near repeats coincide with hotspots. If a large proportion of repeat and near repeat offences are committed in areas that are not hotspots then patterns of repeats and near repeats, and patterns of hotspots are likely to complement each other for informing crime prevention targeting.

Section 2 of the paper describes policing arrangements in New Zealand and the importance of crime prevention in the country's police strategy. In section 3 we describe the theoretical principles that underpin patterns of crime hotspots, repeat victimisation and near repeat victimisation and how these observations have been used for helping prevent crime. Section 4 describes the method used for examining the extent of burglary repeat and near repeat victimisation in New Zealand and for measuring the extent to which crimes following these patterns are located in hotspots. In section 5 the results are described, followed by a discussion of the results (in section 6) and the implications of these findings on crime prevention practice. Conclusions are provided in section 7.

\section{Policing in New Zealand}

New Zealand has a population of 4.5 million people, and is policed by a single national agency - New Zealand Police. Of the 350,000 offences reported to New Zealand Police in a typical recent year, dishonesty offences (burglary, vehicle crime and other types of theft) comprise around half the total. The burglary rate (domestic and commercial) in 2014 was 115.7 per 10,000 population, high in comparison to other western industrialised countries (UNODC, 2014).

In 2010, responding to impending budget challenges and a newly elected government focused on reducing the overall crime rate, New Zealand Police launched an ambitious, transformational policing excellence programme (New Zealand Police, 2014). At the heart of the new police model was a national operating strategy, 'Prevention First'. The Prevention First was founded on the belief that policing works best when targeted to particular (specific) problems, that crime tends to cluster in ways that are not random, and that policing strategies targeted at high-crime areas, active offenders and frequent victims can have a positive impact 
on reducing levels of offending (Evans, 2012). In an effort to help inform New Zealand Police's national burglary reduction strategy, research that examines patterns of domestic burglary and evidence on effective burglary prevention practice would be valuable in informing the types of prevention programmes that were most likely to have an impact in New Zealand.

\section{The use of hotspots, repeat victimisation, and near repeat victimisation for preventing crime}

Hotspot analysis is a technique that helps determine where crime may happen next by using data from the past to identify where crime has previously concentrated. Hotspots form due to certain places exhibiting favourable conditions for the commission of crime, both in terms of the concentration of opportunities to commit crime (Brantingham and Brantingham, 1984) and the routine activities and decision-making of offenders who take advantage of criminal opportunities (Cornish and Clarke, 1986; Cohen and Felson, 1979; Felson, 1998). Hotspot analysis is frequently used in policing to support the targeted deployment of police patrols (Ratcliffe et al, 2011; Sherman et al., 1989; Weisburd and Braga, 2006), to support a strategic targeted approach for crime reduction in persistent problem areas (Chainey and Chapman, 2013), and in Compstat-style performance meetings to help review performance and determine future actions (McDonald, 2002; Walsh, 2001).

Repeat victimisation is the concept of a person or some other target (e.g., a dwelling) being subject to victimisation a number of times. Research into repeat victimisation has shown that, overall, risk doubles following a victimisation, and that repeats occur swiftly after the initial incident (Farrell and Pease, 1993; Polvi et al., 1991) or become more frequent (Bland and Ariel, 2015). Near repeat victimisation is the observed finding that targets near to a recent incident are at a heightened risk of being victimised, with the level of risk decaying with distance from the original target and over time (Johnson and Bowers, 2004; Townsley et al., 2003).

The reasons why repeats and near repeats occur can principally be explained by the boost account, optimal foraging theory, and the flag account. The boost account refers to an offender deciding to return to the same target or nearby targets, boosted by the success of previous crime commission (Pease, 1998). Optimal foraging theory provides a means of 
explaining why the boost account occurs, suggesting that offenders take advantage of other good opportunities to commit crime in the area (observed through the pattern of offences committed in spates) before moving on and avoiding the risk of capture (Johnson et al., 2009). The flag account suggests there is some enduring quality about the target that draws an offender's attention to the target's higher level of vulnerability (Pease, 1998). Different to the boost account and foraging behavioural concepts, the flag account suggests a repeat offence would just as likely be committed by a different offender responding to the same cues of high vulnerability associated with a particular target that drew the attentions of the first offender in the commission of a previous offence against that target. The findings from research into repeat and near repeat victimisation have resulted in the suggestion that these patterns offer a powerful means on which predictions of crime can be made (Bowers et al., 2004) with observations indicating improvements in prediction accuracy over common hotspot analysis methods (Johnson et al., 2008).

The Kirkholt Burglary Prevention Project in Rochdale (UK) was one of the first crime prevention initiatives that took advantage of repeat victimisation patterns to prevent domestic burglary (Forrester et al., 1988). After analysis identified high levels of repeat victimisation on the Kirkholt housing estate, crime prevention efforts were targeted to properties that had previously experienced burglary repeats. The result was an overall reduction in burglary of $53 \%$ across the Kirkholt estate and an $80 \%$ reduction in burglary repeat victimisation (Forrester et al., 1988). The Trafford Experiment in Manchester (UK) was the first initiative designed to specifically counter both repeats and near repeats. The initiative in Trafford involved a crime prevention officer visiting the burgled property within twenty-four hours of the incident to identify ways to reduce a repeat offence. Additionally, police officers were also deployed to conduct door-to-door visits to neighbouring houses on the day after the initial burglary to prevent near repeats from occurring. The impact in Trafford was a burglary reduction of $42 \%$ in the areas that were targeted (Fielding and Jones, 2012). Similar burglary prevention tactics to those introduced in Trafford have been implemented by other police agencies in the UK, USA, and Canada, and have contributed to similar reductions (e.g., Operation Optimal in Leeds led to a $48 \%$ reduction in burglary (Professional Security, 2012)). 
In order for other practitioners to determine if crime prevention initiatives that counter repeats and near repeats could offer sizeable reductions in crime, analysis of the existing extent of repeats and near repeats can offer an estimate of an initiative's possible impact. Studies that have used a one year time-window indicate burglary repeat victimisation accounted for $15 \%$ of all domestic burglaries in Newcastle (England) and $30 \%$ of all domestic burglaries in Birmingham (England) (Chainey and de Silva, 2016). To date, while many studies have reported evidence of near repeat patterns in crime (for an overview see Haberman and Ratcliffe, 2012), no studies have examined the difference in the extent to which near repeats account for the total number of burglaries across several study areas ${ }^{1}$. If an initiative was designed to specifically counter repeats and near repeats, it would be realistic to consider that the level of crime reduction the initiative may yield would be up to the level of the observed extent of repeats and near repeats. Additionally, if many of these repeats and near repeats took place outside of crime hotspots, this would indicate that crime prevention strategies that aimed to counter repeats and near repeats, and the clustering of crime in hotspots would both offer dividends.

\section{Method: study areas, data, and spatial-temporal analysis of domestic burglary}

\subsection{Study areas and recorded crime data}

The areas of Auckland Central, Counties Manukau Central, Wellington, and Kapiti Mana in New Zealand were chosen as the research study areas (these locations are shown in Figure 1).

Auckland is New Zealand's largest city with a population of 1,415,550 (Statistics New Zealand, 2013). The specific area of Auckland Central, situated along the Auckland harbour side and containing Auckland's central business district, is approximately $11 \mathrm{~km}^{2}$ in size, and has a population of 39,501 (Statistics New Zealand, 2013). The main housing type in Auckland Central is high-rise apartment buildings.

Counties Manukau Central is situated south of Auckland and is predominantly composed of two main suburbs - Manurewa and Manukau. Land use in Manurewa is mainly residential

\footnotetext{
${ }^{1}$ The only study that has published measures on the extent to which both repeats and near repeats account for the total number of burglaries is for the Brazilian city of Belo Horizonte (Chainey and de Silva, 2016).
} 
housing, the majority of which are one-family dwellings. Manukau has a large industrial and commercial area in the heart of the suburb. The population of Counties Manukau Central is 82,692 (Statistics New Zealand, 2013).

Wellington is New Zealand's capital city, located at the south-western end of the North Island. The Wellington Central area has a population of 190,959 (Statistics New Zealand, 2013) and covers $290 \mathrm{~km}^{2}$. Wellington's central business district, with some central city apartment housing, occupies one corner of an inlet harbour. Predominantly residential outlying suburbs largely follow a northwest to southeast flow along major traffic-ways or occupy habitable hillsides and valleys that stem out from the central city.

The Kapiti Mana area is located north-east of Wellington and stretches approximately 60 kilometres along the western coast of the North Island. The population of Kapiti Mana is 100,824 (Statistics New Zealand, 2013). There are six small townships in Kapiti Mana where the housing is predominantly one-family dwellings. The primary form of land use in the area is rural farmland.

$<$ figure 1 about here>

Data from the New Zealand Census further show the differences in housing for each of the study areas (see Table 1). In Kapiti Mana and Counties Manukau Central, over three-quarters of all dwellings were separate units (i.e., detached properties), compared to Auckland Central where nearly three-quarters of dwellings were flats and apartments, or dwellings that were adjoined to at least two other housing units (e.g., terraced properties). In Wellington, just under two-thirds of all dwellings were separate units and just over a third were flats and apartments, or dwellings that were adjoined to at least two other housing units. Auckland Central had the highest level of housing density with 1678 households per $\mathrm{km}^{2}$, and Kapiti Mana had by far the lowest level with 86 households per $\mathrm{km}^{2}$.

$<$ table 1 about here> 
The four study areas were considered to be representative of both the range of housing types across New Zealand and the range in domestic burglary levels experienced across the country. The study areas also fall into natural pairs due to their geographical proximity to each other. Additionally, differences in the results between the study areas that constitute each pair of proximal areas were considered to be of practical interest to New Zealand Police due to each pair falling under the same regional police command.

Recorded crime data on domestic burglary from New Zealand Police for the period April 2013 to March 2014 were used for the research. Crime data for this one year period was considered to be sufficient for an analysis of repeat and near repeat victimisation patterns. Table 1 shows that the number of recorded domestic burglaries committed in each area between April 2013 and March 2014 ranged between 345 in Auckland Central to 1170 in Counties Manukau Central. Counties Manukau Central experienced the highest domestic burglary rate, being over twice the burglary rate in Auckland Central and Wellington and five times greater than the domestic burglary rate in Kapiti Mana.

\subsection{Identifying repeats, near repeats and whether they are located in hotspots}

Repeat offences of domestic burglary were identified using a two stage approach. The first stage involved selecting those records where the geographic coordinates for the burglary were the same as that for another offence. The address details for each of these offences were then checked to ensure that each offence corresponded to the same dwelling. If the dwellings were different but the geographic coordinates were the same (e.g., burglaries to two dwellings within the same apartment block), these records were removed from the list of repeats. The second stage identified repeats based on the same text string details recorded in the address field of the crime record. This meant that addresses identified as repeats based on their geographic coordinates could be corroborated with the text string based search.

Near repeats were identified using the Near Repeat Calculator (Ratcliffe, 2009). This near repeat analysis involved examining the distance and time between burglary incidents to determine if the pattern of near repeats was significant. The spatial bandwidth in the Near Repeat Calculator was set to 100 metres and five bands were applied (i.e., 1 to $100 \mathrm{~m}, 101$ to $200 \mathrm{~m}, 201$ to $300 \mathrm{~m}, 301$ to $400 \mathrm{~m}$ and 401 to $500 \mathrm{~m}$ ). Additionally, the analysis included 
examining patterns for the same location. The temporal bandwidth in the Near Repeat Calculator was set to 7 days and four bands were applied (i.e., 0 to 7 days, 8 to 14 days, 15 to 21 days, 22 to 28 days). Additional analysis was conducted to determine the number of offences committed within 100 metres and 7 days of an originator offence, 200 metres and 7 days of an originator offence and within $300 \mathrm{~m}$ and 7 days of an originator offence. The spatial and temporal bandwidths and the number of bands were chosen as they offered a practical means for New Zealand police officers to conceptualize the extent of near repeat victimisation.

Burglaries that took place at the same location and within the temporal bands examined were reviewed to determine if these crime records related to burglaries to the same dwelling or to a different dwelling but in the same building. Crime records relating to the same dwelling were removed from the near repeat analysis as these were repeats. Crime records relating to a different dwelling but within the same building as a previous recent offence were included as near repeats.

Hotspots of burglary for each study area were produced using kernel density estimation (KDE). While many other techniques exist for producing hotspot maps of crime (e.g., for a recent review see Adepeju et al, 2016), KDE is the main technique that police agencies continue to use (including New Zealand Police) for examining crime hotspots (Chainey et al, 2008; Hart and Zandbergen, 2012)2. To allow for comparisons between the study areas, hotspots were controlled to represent the smallest area within which $25 \%$ of the proportion of all domestic burglaries in each study area concentrated, following the method used by Weisburd (2015) to determine areas of high crime concentration. The number of all burglaries, burglary repeats and near repeats that were located within hotspots were calculated for each of the study areas.

\section{Results}

\subsection{Repeat victimisation}

\footnotetext{
${ }^{2}$ Bandwidth size and cell size for kernel density estimation were chosen following the procedure advised in Chainey et al., 2008.
} 
Between April 2013 and March 2014, 185 homes in the four study areas in New Zealand were known to have experienced more than one burglary, accounting for 393 burglaries in total and $13 \%$ of all recorded domestic burglaries (see Table 2). There were 208 repeat domestic burglaries in the four study areas between 2013 and 2014, equating to $7 \%$ of all recorded domestic burglaries during this period. There were, however, differences in the levels of burglary repeats in the four study areas. In Counties Manukau Central, one in ten of all burglaries were repeats, whereas in the three other study areas, repeats accounted for one in every twenty burglaries. In terms of crime volume, burglary repeats accounted for 114 offences in Counties Manukau Central but for only 16 offences in Auckland Central.

$<$ table 2 about here $>$

\subsection{Near repeat victimisation}

Tables $3 a$ to $3 d$ show that a pattern of burglary near repeats was evident in all study areas $(p<0.05)$, but that the extent of these patterns varied. A near repeat pattern was evident across many of the spatial and temporal bands in Counties Manukau Central and Wellington, with the strongest presence of near repeats being closest to and soonest after a previous incident. For example, in Wellington, all four distance bands of the same dwelling, 1 to 100 $\mathrm{m}, 101$ to $200 \mathrm{~m}$ and 201 to $300 \mathrm{~m}$, and within 0 to 7 days of a previous incident were significant $(p<0.05)$, with the presence of near repeats being greatest for dwellings closest to the initial incident. For Wellington, the chance of another incident taking place at the same dwelling within a week was 3.1 times greater than expected, compared to 0.3 times greater than expected within 201 to $300 \mathrm{~m}$. The pattern of near repeats was significant $(p<0.05)$ for only four of the twenty-four spatio-temporal bands in Auckland Central and for only three in Kapiti Mana.

$<$ table 3 about here $>$

Table 4 shows that burglary near repeats, defined in terms of offences taking place within 200 $\mathrm{m}$ and 7 days of a previous offence, accounted for 469 burglaries in the four study areas, equivalent to just under one in seven of all burglaries committed between April 2013 and March 2014. Table 4 also shows that the extent of burglary near repeats as a proportion of 
all burglaries varied in each of the four study areas. In Auckland Central and Counties Manukau Central $18 \%$ of all burglaries took place within $200 \mathrm{~m}$ and 7 days of a previous offence. However, in Kapiti Mana only $7 \%$ of all burglaries took place within $200 \mathrm{~m}$ and 7 days of a previous offence.

$<$ table 4 about here>

\subsection{Repeats and near repeats in crime hotspots}

Figures $2 \mathrm{a}$ to $2 \mathrm{f}$ show the distribution of burglary repeats and near repeats in relation to burglary hotspots for each of the four study areas. While several repeats and near repeats were located in the main burglary hotspots for each study area, many were not. For example (and as listed in Table 5), in Wellington of the 246 offences that took place in hotspots, 81 of these were repeats and near repeats (accounting for a third of all repeats and near repeats in Wellington). Wellington hotspots contained 165 other burglaries that did not follow repeat or near repeat patterns. Similarly, for the three other study areas at least half of the burglaries that were repeats or near repeats were not located within hotspots. These findings indicate that while many burglaries that follow repeat and near repeat patterns contributed to the cluster of crimes located in hotspots, the majority of repeats and near repeats took place outside of crime hotspots.

$<$ figure 2 about here>

$<$ table 5 about here $>$

\section{Discussion and implications}

Previous studies that have analysed repeat victimisation have indicated that burglary repeats account for 15 to $30 \%$ of all domestic burglary, offering promise that crime prevention measures that aim to counter repeats could bring reductions in burglary equivalent to the extent of the observed pattern. Across the four study areas in New Zealand, burglary repeats accounted for only $7 \%$ of all domestic burglaries. While crime prevention efforts to reduce the heightened risk of burglaries to previously burgled properties in New Zealand would likely have some impact on reducing burglary overall, these efforts may not yield the same level of 
reductions reported from studies such as the $53 \%$ reduction in burglary following the Kirkholt Burglary Prevention Project (Forrester et al., 1988). Additionally, the results from the current research show that the extent of burglary repeats varied between the four study areas, indicating that in Counties Manukau Central where the level of repeats were much higher than those in the three other study areas, the same crime prevention activity (designed to counter repeats) would likely have a greater impact than in the three other areas. For example, drawing from the good practice of a crime prevention officer visiting a dwelling within twenty-four hours of it being burgled to provide advice that reduces the heightened risk of further burglaries occurring, in Counties Manukau Central this could result in a $10 \%$ reduction in burglary if all repeats were countered but would likely only yield a $5 \%$ reduction in any of the other four areas because of the general lower presence of a burglary repeat victimisation pattern.

Similarly, levels of burglary near repeats were found to vary between the four study areas. Previous studies have reported on the significant presence of near repeats, but for practitioners keen to prevent burglaries, determining the proportion of all burglaries that follow near repeat patterns provides an indication of how many burglaries could be prevented. Practice from Trafford and Leeds (as reported in section 3) suggested impressive burglary reductions of up to $48 \%$ through simple targeted interventions to neighbouring properties following a recent burglary. Crime prevention practitioners for other areas intent on adopting the same practice would also hope for similar burglary reductions. While how a programme is implemented is a crucial part of its replication, understanding the context within which the practice is applied and measuring the likely returns from replication is equally as important. In the four study areas, the extent of near repeats varied (see Table 5), suggesting that if all attempts to counter near repeats were successful (within $200 \mathrm{~m}$ and 7 days of the previous offence), the upper limit of burglary reduction would be $18 \%$ in Auckland Central and Counties Manukau Central but may only be 7 \% in Kapiti Mana.

Previous research (as reported in Section 3) has also suggested that repeats and near repeats coincide within hotspots and that the patterning principles of repeats and near repeats offer a more powerful means for predicting crime than hotspot analysis. The current research has shown that while many repeats and near repeats took place in the burglary hotspots in each 
of the four study areas, the majority of the offences that followed these repeat and near patterns did not. While the size of the areas defined as hotspots has an obvious influence on these results ${ }^{3}$, these findings have two key implications. The first relates to the benefits available in conducting both repeat and near repeat analysis, and hotspot analysis (as a form of crime concentration analysis) for the prediction of crime. While analysis of repeat and near repeat patterns can indicate where a crime may occur soon after an initial incident, many additional crimes that do not follow repeat and near repeat patterns cluster to form hotspots where crime is likely to persist in the future. An analysis of repeats and near repeats and of crime concentration can, therefore, in combination offer a powerful means for determining where crime is likely to occur. In this study, KDE was used to identify areas of crime concentration due to its common use by police agencies. Other techniques for examining crime concentration could be used, such as self-exciting point process modelling or the examination of crime concentration at the street segment level, in order to improve the observations made using KDE.

The second implication of these findings relates to crime prevention practice. From an analysis of repeats, near repeats and hotspots, the current research has presented a method that practitioners can replicate for generating a measure of the potential crime prevention yield from countering these observed patterns. Table 6 lists the potential burglary reduction yield from countering the observed levels of repeats, near repeats and other burglaries within hotspots for each of the four study areas. For example, in Counties Manukau Central, repeats and near repeats (within $200 \mathrm{~m}$ and 7 days) accounted for $28 \%$ of all burglaries, indicating that crime prevention measures that successfully countered these predictable patterns could yield a reduction in burglary of up to $28 \%$. Additionally, a further $17 \%$ of all burglaries concentrated in crime hotspots, indicating that a successful programme that was targeted at tackling the conditions responsible for the concentration of crime at these locations could yield an additional $17 \%$ reduction in burglary ${ }^{4}$. In total, crime prevention activity that was designed to counter burglary repeats, near repeats and hotspots could potentially yield a 45 $\%$ reduction in burglary in Counties Manukau Central. The analysis of repeats, near repeats

\footnotetext{
${ }^{3}$ Albeit, a parameter defined by Weisburd, 2015, was used to determine the areas covered by crime hotspots.

${ }^{4}$ Furthermore, effective problem-oriented crime prevention programmes could yield additional reductions via a diffusion of benefit from the targeted activity (Bowers et al., 2011).
} 
and crime hotspots can also be used to help indicate the types of crime prevention activity that may yield the greatest reduction returns. While one in four of all burglaries in Counties Manukau Central were repeats or near repeats, in Kapiti Mana only one in eight followed these same patterns. Also, in Kapiti Mana $19 \%$ of all other burglaries were located in crime hotspots. These results for Kapiti Mana suggest that crime prevention activity that was targeted towards addressing the conditions responsible for the concentration of crime in the hotspots may yield greater reduction returns than a programme of activity that attempted to counter repeats and near repeats.

$<$ table 6 about here $>$

The observed variations in the patterns of repeat and near repeat victimisation have prompted consideration on the reasons for these variations and signalled opportunities for further research. The boost account is one of the main reasons posited for explaining repeats and near repeats, with an offender returning to forage for other nearby opportunities following successful crime commission. On this basis (and as a potential area of future research), it is hypothesised that an examination of the geographic distribution of offenders (particularly those who are known to be prolific in committing burglaries) could offer insights in to why variations exist in the extent of repeats and near repeats. The variation may also be related to differences in the homogeneity of housing. Future research should examine whether places that experience higher rates of near repeats are areas where houses are most similar, and hence offer the best conditions for a boosted offender to forage for other nearby opportunities.

Research that has examined near repeats has been based on distance measures from previous incidents. Within a single study area, a distance measure is practical, but when examining differences between areas the resulting measurements of repeats and near repeats do not offer a direct like-for-like comparison due to differences in housing density. This means that differences in the extent of near repeats within a set distance (e.g., $200 \mathrm{~m}$ ) of a previous incident would naturally occur when comparisons are made between study areas of different housing density. This calls for research on near repeats that examines the use of other metrics that allow for closer like-for-like comparisons between urban, suburban 
and rural areas where the distribution of houses, and hence opportunities for crime, is different. Additionally, further research could examine in more detail how the temporal profile of near repeats could better inform crime prevention practice. The current study used

7 day bands for examining the extent of near repeats. While this enabled a comparison between areas on the extent of near repeats, a more detailed analysis of the near repeat risk profile (as illustrated in Table 3 ) for different time bands may result in determining more specifically the periods of heightened risk that require countering.

\section{Conclusions}

Research that has examined patterns of repeat and near repeat victimisation has typically focused on examining the presence of these patterns rather than considering the extent to which these patterns support the applications to which they have most been applied - crime prediction and crime prevention. In this paper, the examination of repeats and near repeats in four distinct geographical areas has shown that the extent of these patterns vary, which in turn means there is variation in the estimated prevention benefits that repeat and near repeat patterns can offer. The research also showed that in all study areas at least half of the burglaries that followed patterns of repeats and near repeats were not located within crime hotspots. This means that rather than considering the use of repeat and near repeat patterns as a superior means of informing the prevention of crime, significant value remains in using crime concentration techniques, particularly when repeats/near repeats and areas of high crime concentration show different locations for resource targeting.

The research results strongly suggest that burglary prevention strategies that have shown clear evidence of success in areas where there are high levels of repeats are unlikely to yield the same level of total benefit if applied in the same ways in New Zealand. Equally, because there were large differences in the levels of repeats and near repeats across the four study areas, there would be significant variation in the benefits that would be achieved from prediction and prevention approaches that used these patterning principles. At a time when police agencies are increasingly seeking to learn from the practice of others and apply what they have observed as being effective crime prevention programmes to the problems they are trying to address, the use of repeats and near repeats as a prediction and prevention framework is unlikely to yield consistent positive results. Collectively, our findings illustrate 
the critical importance of understanding the specific patterning of crime and the context within which these patterns form for accurately informing the types of crime prevention programmes that are most likely to yield the greatest crime reduction benefits.

\section{References}

Adepeju, M., Rosser, G. and Cheng, T (2016), "Novel evaluation metrics for sparse spatiotemporal point process hotspot predictions - a crime case study", International Journal of Geographical Information Science 30:11: 2133-2154.

Bland, M. and Ariel B. (2015), "Targeting escalation in reported domestic abuse: evidence from 36,000 callouts", International Criminal Justice Review 25:30-53.

Bennett, T. (1995), "Identifying, explaining and targeting burglary 'Hot Spots'”, European Journal on Criminal Policy and Research 3:113-123.

Bowers, K.J., Johnson, S., and Pease, K. (2004), "Prospective hotspotting: the future of crime mapping?", British Journal of Criminology 44:5:641-658.

Bowers, K., Johnson, S., Guerette, R.T., Summers, L., and Poynton, S. (2011). Spatial displacement and diffusion of benefits among geographically focused policing initiatives. Campbell Systematic Reviews 2011.3.

Braga, A., Papachristos, A., Hureau, D. (2012), Hot spots policing effects on crime, The Campbell Collaboration: Oslo, Norway.

Brantingham, P.J., and Brantingham, P.L. (1984), Patterns in crime, Macmillan: New York.

Chainey, S.P., and Chapman, J. (2013), "A problem-oriented approach to the production of Strategic Intelligence Assessments", Policing: An International Journal of Strategies and Management 36:3:474-490. 
Chainey, S.P. and de Silva, B. (2016), "Examining the extent of repeat and near repeat victimisation of domestic burglaries in Belo Horizonte, Brazil", Crime Science 5:1:1-10.

Chainey, S.P., Tompson, L., Uhlig,S. (2008), "The utility of hotspot mapping for predicting spatial patterns of crime", Security Journal 21:1-2.

Cohen, L.E., and Felson, M. (1979), "Social change and crime rate trends: A Routine Activity Approach", American Sociological Review 44:588-608.

Evans, R.M. (2012), "The diamond matrix: a science-driven approach to policing with crime intelligence", Policing: a Journal of Policy and Practice 6(2):133-143.

Esri (2016), Crime Analysis Toolbox: Repeat and Near Repeat Analysis, available at http://solutions.arcgis.com/local-government/help/repeat-and-near-repeat-analysis/ (accessed 24 November 2016).

Cornish, D., and Clarke, R. (1986), The Reasoning Criminal: Rational Choice Perspectives on Offending, Springer-Verlag: New York.

Farrell, G., and Pease, K. (1993), Once bitten, twice bitten: repeat victimisation and its implications for crime prevention, Crime Prevention Unit Paper 46. Home Office: London.

Felson, M. (1998), Crime and everyday life: Impact and implications for society, Pine Forge Press: Thousand Oaks, CA.

Fielding M., and Jones V. (2012), “Disrupting the optimal forager: predictive risk mapping and domestic burglary reduction in Trafford, Greater Manchester", International Journal of Police Science and Management 14:1:30-41.

Forrester, D., Chatterton, M., and Pease, K. (1988), The Kirkholt Burglary Prevention Project, Rochdale, Crime Prevention Unit Paper 13, Home Office: London. 
Haberman, C.P., and Ratcliffe, J.H. (2012), "The predictive policing challenges of near repeat armed street robberies", Policing: A Journal of Policy and Practice 6:2:151-166.

Hart, T.C. and Zandbergen, P.A. (2012), Effects of data quality on predictive hotspot mapping. Final Technical Report Document Number 239861, US National Institute of Justice: Washington D.C.

IFMPT (2016), PRECOBS - Pre Crime Observation System, available at http://www.ifmpt.com/ (accessed 24 November 2016)

Johnson S., Bowers, K., and Hirschfield, A. (1997), "New insights into the spatial and temporal distribution of repeat victimization", British Journal of Criminology 37(2):224-241.

Johnson S., Bowers K.J., Birks D., and Pease K. (2008), "Predictive mapping: accuracy for different units of analysis and the role of the environmental backcloth", in D. Weisburd, W. Bernasco and G. Bruinsma (Eds.) Putting Crime in it's Place: Units of Analysis in Spatial Crime Research, Springer: New York.

Johnson, S.D., Summers, L., and Pease, K. (2009). "Offender as forager? A direct test of the boost account of victimization", Journal of Quantitative Criminology 25:181-200.

McDonald, P.P. (2002), Managing Police Operations: Implementing the New York Crime Model - CompStat, Wadsworth: Belmont, CA.

New Zealand Police (2014), Policing Excellence: The Transformation of New Zealand Police 2009-2014, available at http://www.police.govt.nz/sites/default/files/publications/policingexcellence-closure.pdf (accessed 24 November 2016).

Pease, K. (1998), Repeat victimization: taking stock, Home Office Police Research Group, crime detection and prevention series, paper 90, Home Office: London. 
Polvi, N., Looman, T., Humphries, Ch., and Pease, K., (1991), "The Time-Course of Repeat Burglary Victimization", British Journal of Criminology 31:411-414.

PredPol (2013), Policing meets big data, available at http://www.predpol.com/about/ (accessed 24 November 2016).

Professional Security (2012) Tackling burglary, available at http://www.professionalsecurity.co.uk/news/case-studies/tackling-burglary/ (accessed 24 November 2016).

Ratcliffe, J.H. (2009), Near Repeat Calculator, available at http://www.jratcliffe.net/software/ (accessed 24 November 2016).

Ratcliffe, J.H., Taniguchi, T., Groff, E., and Wood, J. (2011), "The Philadelphia Foot Patrol Experiment: A randomized controlled trial of police patrol effectiveness in violent crime hotspots", Criminology 49:3:795-831.

Sherman, L., Gartin, P. and Buerger, M.E. (1989), “Hot spots of predatory crime: Routine activities and the criminology of place", Criminology 27:27-55.

Statistics New Zealand (2013), The New Zealand Census 2013, available at, http://www.stats.govt.nz/Census/2013-census.aspx (accessed 22 May 2015).

Townsley, M, R. Homel and J. Chaseling (2000), "Repeat burglary victimisation: spatial and temporal patterns", Australian and New Zealand Journal of Criminology 33(I):37-63.

Townsley, M., Homel, R. and Chaseling, J. (2003), "Infectious burglaries: a test of the near repeat hypothesis", British Journal of Criminology, 43 (3), 615-633.

Walsh, W. (2001), "Compstat: An Analysis of an Emerging Police Paradigm", Policing: An International Journal of Police Strategies and Management 24:3:347-363. 
Weisburd, D.L. (2015), "The law of crime concentration and the criminology of place", Criminology, 53:2:133-157.

Weisburd, D.L., and Braga, A.A. (2006), "Hot spots policing as a model for police innovation" in D.L. Weisburd and A.A. Braga (Eds.) Police Innovation: Contrasting Perspectives, Cambridge University Press: New York.

Weisel, D.L. (2005) Analyzing Repeat Victimization POP Center Tool Guide Number 4, Center for Problem-Oriented Policing.

UNODC (2014), UNODC international burglary, car theft and housebreaking statistics, avaiable at https://www.unodc.org/unodc/en/data-and-analysis/statistics/data.html. (Accessed 27 May 2015). 


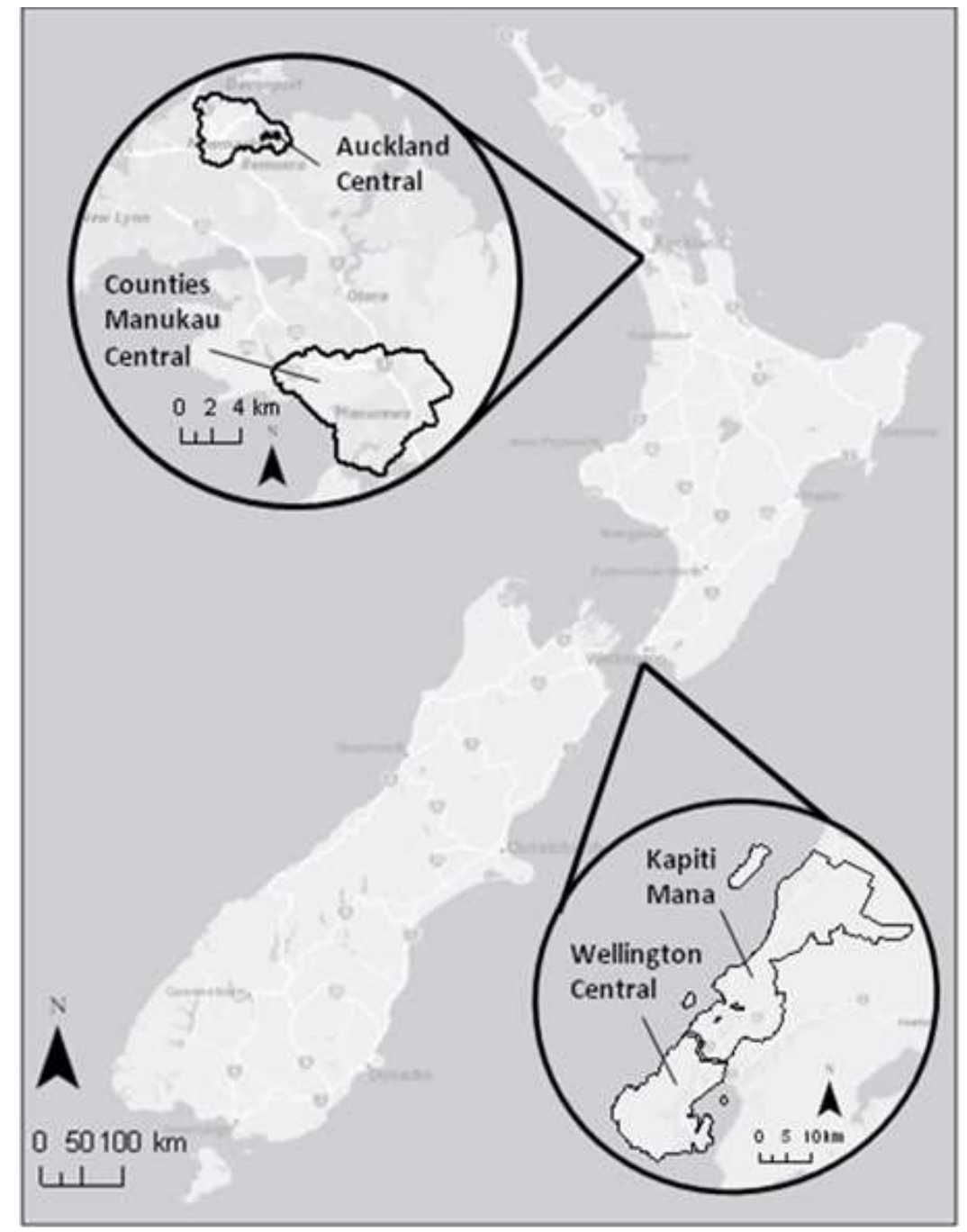

Figure 1. The location of the four study areas in New Zealand 

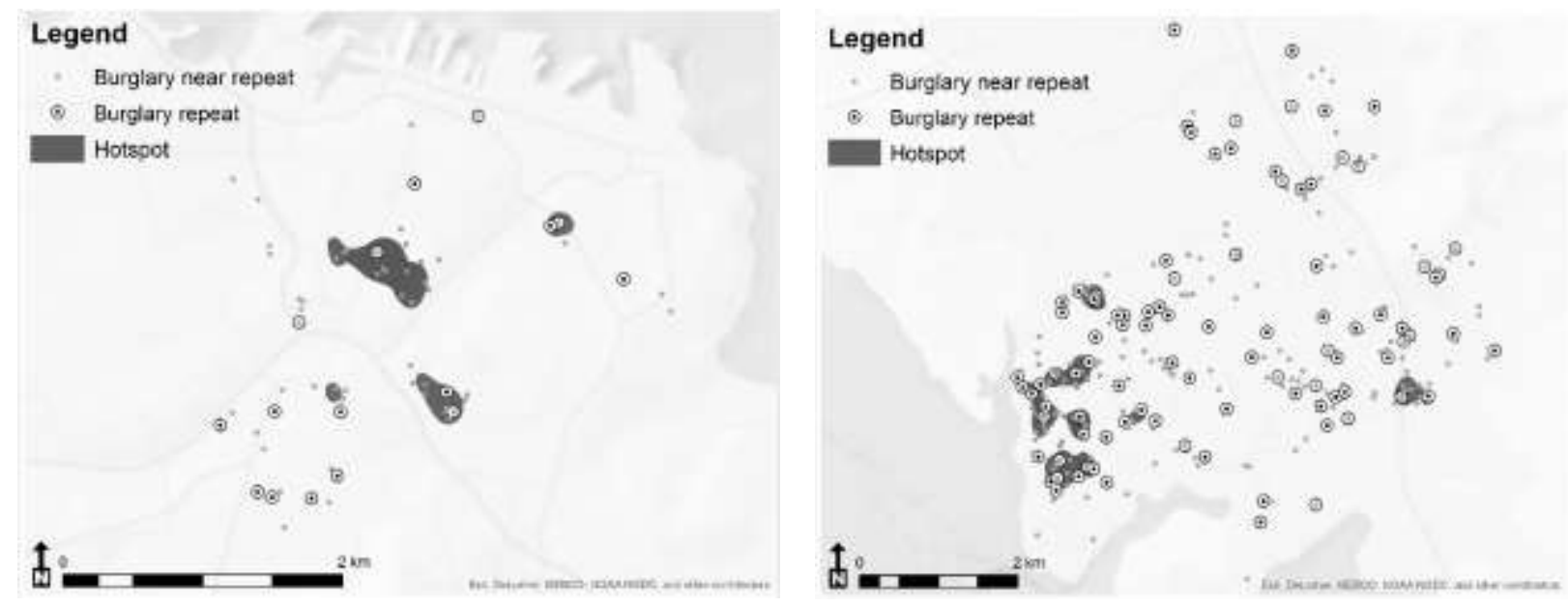

(a) Auckland Central

(b) Counties Manukau Central
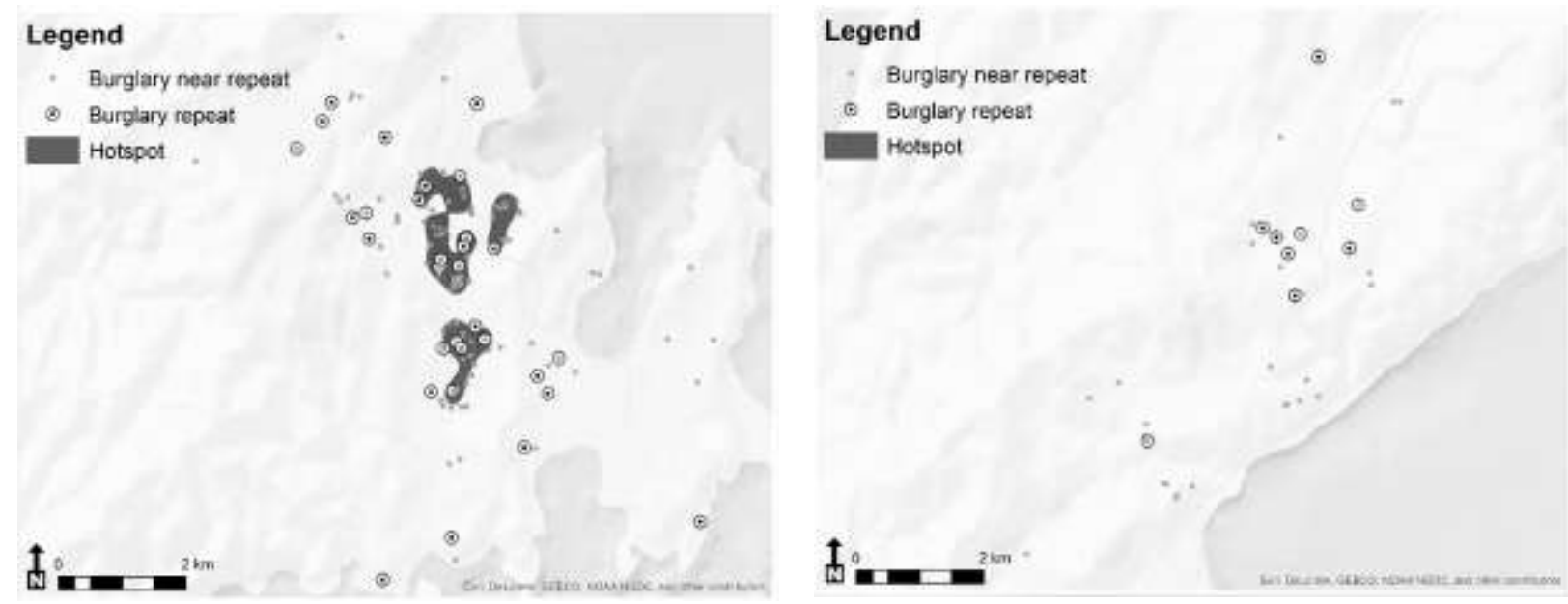

(c) Wellington - southern part of study area

(d) Wellington - northern part of study area
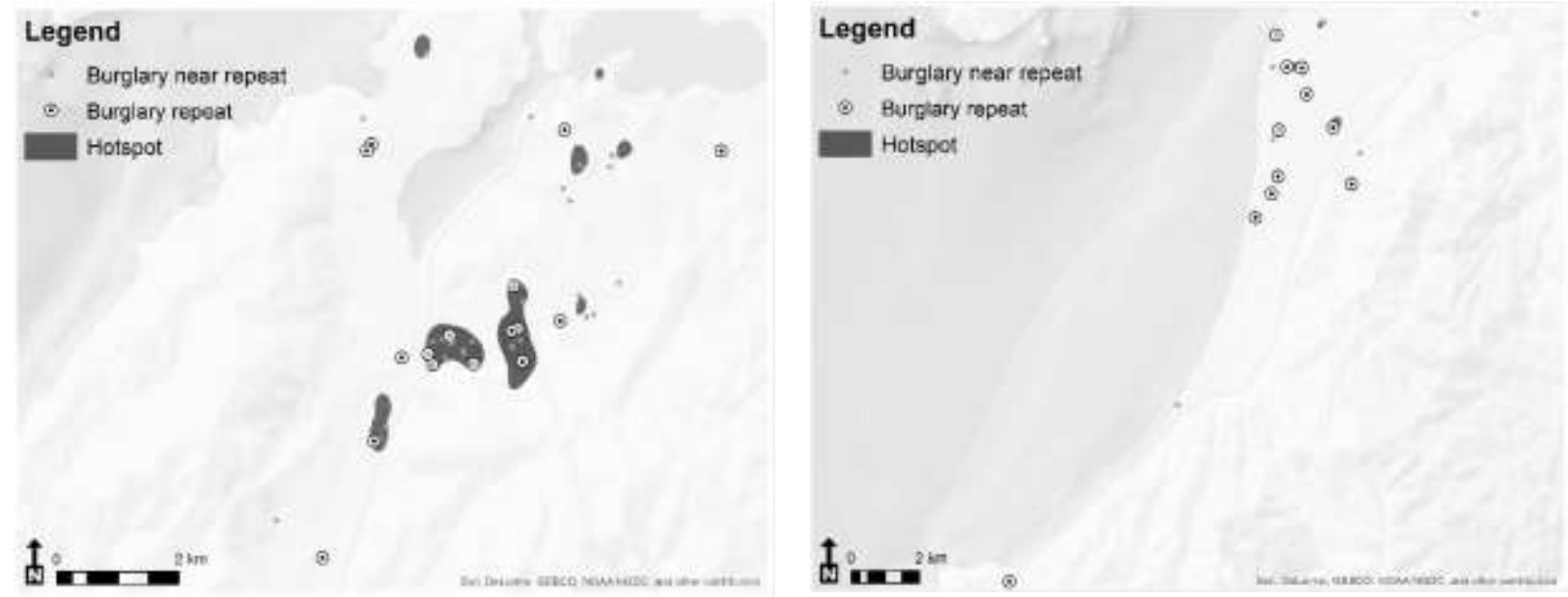

(e) Kapiti Mana - southern part of study area

(f) Kapiti Mana - northern part of study area

Figure 2. Burglary hotspots and the locations of repeats and near repeats in (a) Auckland Central, (b) Counties Manukau Central, (c) and (d) Wellington, and (e) and (f) Kapiti Mana. 
Table 1. Housing type, population density (Statistics New Zealand, 2013) and levels of domestic burglary

\begin{tabular}{|l|c|c|c|c|}
\hline Measure & $\begin{array}{c}\text { Auckland } \\
\text { Central }\end{array}$ & $\begin{array}{c}\text { Counties } \\
\text { Manukau } \\
\text { Central }\end{array}$ & Wellington & Kapiti Mana \\
\hline Housing type & $17 \%$ & $78 \%$ & $58 \%$ & $80 \%$ \\
\hline Dwellings that are separate houses & $73 \%$ & $12 \%$ & $37 \%$ & $15 \%$ \\
\hline $\begin{array}{l}\text { Dwellings that are units with two or } \\
\text { more flats, apartments, or adjoining } \\
\text { units }\end{array}$ & $10 \%$ & $10 \%$ & $5 \%$ & $5 \%$ \\
\hline $\begin{array}{l}\text { 'Other' dwellings or 'not further } \\
\text { defined' }\end{array}$ & 1678 & 482 & 657 & 86 \\
\hline Housing density & 14.2 & 51.1 & 25.4 & 9.8 \\
\hline $\begin{array}{l}\text { Average number of households per } \\
\text { Km }\end{array}$ & & & & \\
\hline $\begin{array}{l}\text { Domestic burglary (April 2013 to } \\
\text { March 2014) }\end{array}$ & 345 & 1170 & 984 & 645 \\
\hline $\begin{array}{l}\text { Number of recorded offences } \\
\text { Rate per 1000 households }\end{array}$ & & & \\
\hline
\end{tabular}


Table 2. Domestic burglaries and repeat burglaries between April 2013 and March 2014

\begin{tabular}{|l|c|c|c|c|}
\hline & Burglaries & $\begin{array}{c}\text { Dwellings with } \\
\text { >1 burglary (\% } \\
\text { of all burgled } \\
\text { dwellings) }\end{array}$ & $\begin{array}{c}\text { Burglaries at } \\
\text { repeat dwellings } \\
\text { (\% of all } \\
\text { burglaries) }\end{array}$ & $\begin{array}{c}\text { Repeats (\% of } \\
\text { all burglaries) }\end{array}$ \\
\hline Total (four study areas) & 3144 & $185(6 \%)$ & $393(13 \%)$ & $208(7 \%)$ \\
\hline Auckland Central & 345 & $16(5 \%)$ & $32(9 \%)$ & $16(5 \%)$ \\
\hline Counties Manukau Central & 1170 & $98(9 \%)$ & $212(18 \%)$ & $114(10 \%)$ \\
\hline Wellington & 984 & $42(4 \%)$ & $89(9 \%)$ & $47(5 \%)$ \\
\hline Kapiti Mana & 645 & $29(5 \%)$ & $60(9 \%)$ & $31(5 \%)$ \\
\hline
\end{tabular}


Table 3. The presence of burglary near repeats in (a) Auckland Central, (b) Counties Manukau Central, (c) Wellington and (d) Kapiti Mana $(p<0.05)$. Blank cells represent non-significant results.

(a) Auckland Central

\begin{tabular}{|l|c|c|c|c|}
\hline & $\mathbf{0}$ to $\mathbf{7}$ days & $\mathbf{8}$ to $\mathbf{1 4}$ days & $\mathbf{1 5}$ to $\mathbf{2 1}$ days & $\mathbf{2 2}$ to $\mathbf{2 8}$ days \\
\hline Same dwelling & 4.1 & & & \\
\hline $\mathbf{1}$ to $\mathbf{1 0 0}$ metres & & & 1.6 & \\
\hline $\mathbf{1 0 1}$ to $\mathbf{2 0 0}$ metres & & 1.3 & & \\
\hline $\mathbf{2 0 1}$ to $\mathbf{3 0 0}$ metres & 1.6 & & & \\
\hline $\mathbf{3 0 1}$ to $\mathbf{4 0 0}$ metres & & & & \\
\hline $\mathbf{4 0 1}$ to $\mathbf{5 0 0}$ metres & & & & \\
\hline
\end{tabular}

(b) Counties Manukau Central

\begin{tabular}{|l|c|c|c|c|}
\hline & $\mathbf{0}$ to $\mathbf{7}$ days & $\mathbf{8}$ to $\mathbf{1 4}$ days & $\mathbf{1 5}$ to $\mathbf{2 1}$ days & $\mathbf{2 2}$ to $\mathbf{2 8}$ days \\
\hline Same dwelling & 3.2 & 3.2 & & \\
\hline $\mathbf{1}$ to $\mathbf{1 0 0}$ metres & 1.7 & 1.2 & & 1.3 \\
\hline $\mathbf{1 0 1}$ to $\mathbf{2 0 0}$ metres & 1.3 & & & 1.2 \\
\hline $\mathbf{2 0 1}$ to $\mathbf{3 0 0}$ metres & & & & \\
\hline $\mathbf{3 0 1}$ to $\mathbf{4 0 0}$ metres & 1.2 & & & \\
\hline $\mathbf{4 0 1}$ to $\mathbf{5 0 0}$ metres & & 1.1 & & \\
\hline
\end{tabular}

(c) Wellington

\begin{tabular}{|l|c|c|c|c|}
\hline & $\mathbf{0}$ to $\mathbf{7}$ days & $\mathbf{8}$ to $\mathbf{1 4}$ days & $\mathbf{1 5}$ to $\mathbf{2 1}$ days & $\mathbf{2 2}$ to $\mathbf{2 8}$ days \\
\hline Same dwelling & 3.1 & & & \\
\hline $\mathbf{1}$ to $\mathbf{1 0 0}$ metres & 2.1 & 1.4 & 1.6 & \\
\hline $\mathbf{1 0 1}$ to $\mathbf{2 0 0}$ metres & 1.6 & & 1.6 & \\
\hline $\mathbf{2 0 1}$ to $\mathbf{3 0 0}$ metres & 1.3 & 1.3 & 1.2 & \\
\hline $\mathbf{3 0 1}$ to $\mathbf{4 0 0}$ metres & & & 1.3 & \\
\hline $\mathbf{4 0 1}$ to $\mathbf{5 0 0}$ metres & 1.2 & 1.2 & & \\
\hline
\end{tabular}

(d) Kapiti Mana

\begin{tabular}{|l|c|c|c|c|}
\hline & $\mathbf{0}$ to $\mathbf{7}$ days & $\mathbf{8}$ to $\mathbf{1 4}$ days & $\mathbf{1 5}$ to $\mathbf{2 1}$ days & $\mathbf{2 2}$ to $\mathbf{2 8}$ days \\
\hline Same dwelling & 9.5 & & & \\
\hline $\mathbf{1}$ to $\mathbf{1 0 0}$ metres & & & & \\
\hline $\mathbf{1 0 1}$ to $\mathbf{2 0 0}$ metres & & & & \\
\hline $\mathbf{2 0 1}$ to $\mathbf{3 0 0}$ metres & 1.5 & & & \\
\hline $\mathbf{3 0 1}$ to $\mathbf{4 0 0}$ metres & & & & \\
\hline $\mathbf{4 0 1}$ to $\mathbf{5 0 0}$ metres & & & 1.4 & \\
\hline
\end{tabular}


Table 4. The extent of burglary near repeats for three different spatio-temporal bands

\begin{tabular}{|l|c|c|c|}
\hline & $\begin{array}{c}\text { Within } \mathbf{1 0 0} \text { m and } \\
\mathbf{7} \text { days }\end{array}$ & $\begin{array}{c}\text { Within } \mathbf{2 0 0} \mathbf{~ m} \text { and } \\
\mathbf{7} \text { days }\end{array}$ & $\begin{array}{c}\text { Within } \mathbf{3 0 0} \mathbf{~ m} \text { and } \\
\mathbf{7} \text { days }\end{array}$ \\
\hline Total (all four study areas) & $181(6 \%)$ & $469(15 \%)$ & $787(25 \%)$ \\
\hline Auckland Central & $30(9 \%)$ & $61(18 \%)$ & $107(31 \%)$ \\
\hline Counties Manukau Central & $62(5 \%)$ & $208(18 \%)$ & $360(31 \%)$ \\
\hline Wellington & $70(7 \%)$ & $156(16 \%)$ & $243(25 \%)$ \\
\hline Kapiti Mana & $19(3 \%)$ & $44(7 \%)$ & $77(12 \%)$ \\
\hline
\end{tabular}


Table 5. The proportion of burglaries, repeats and near repeats located within and not within hotspots

\begin{tabular}{|l|l|l|l|l|}
\hline & $\begin{array}{l}\text { Burglaries } \\
\text { in hotspots }\end{array}$ & $\begin{array}{l}\text { Repeats in } \\
\text { hotspots }(\% \\
\text { of repeats } \\
\text { in hotspots) }\end{array}$ & $\begin{array}{l}\text { Near repeats } \\
\text { in hotspots near } \\
\text { repeats in } \\
\text { hotspots) }\end{array}$ & $\begin{array}{l}\text { Repeats and near } \\
\text { repeats not in } \\
\text { hotspots (\% of } \\
\text { repeats and near } \\
\text { repeats) }\end{array}$ \\
\hline Auckland Central & 86 & $6(38 \%)$ & $27(44 \%)$ & $44(57 \%)$ \\
\hline Counties Manukau Central & 293 & $30(26 \%)$ & $62(30 \%)$ & $230(71 \%)$ \\
\hline Wellington & 246 & $15(32 \%)$ & $66(42 \%)$ & $122(60 \%)$ \\
\hline Kapiti Mana & 161 & $14(45 \%)$ & $23(52 \%)$ & $38(51 \%)$ \\
\hline
\end{tabular}


Table 6. The potential burglary reduction yield from countering repeats, near repeats and the concentration of other burglaries in crime hotspots for the four study areas

\begin{tabular}{|l|l|l|l|}
\hline \multirow{2}{*}{} & \multicolumn{3}{|l|}{ Potential burglary reduction yield from: } \\
\cline { 2 - 4 } & $\begin{array}{l}\text { Countering } \\
\text { repeats and near } \\
\text { repeats }\end{array}$ & $\begin{array}{l}\text { Countering other } \\
\text { burglaries in } \\
\text { hotspots }\end{array}$ & $\begin{array}{l}\text { Countering repeats, } \\
\text { near repeats, and } \\
\text { other burglaries in } \\
\text { hotspots }\end{array}$ \\
\hline Auckland Central & $77(22 \%)$ & $53(15 \%)$ & $130(38 \%)$ \\
\hline Counties Manukau Central & $322(28 \%)$ & $201(17 \%)$ & $523(45 \%)$ \\
\hline Wellington & $203(21 \%)$ & $165(17 \%)$ & $368(37 \%)$ \\
\hline Kapiti Mana & $75(12 \%)$ & $124(19 \%)$ & $199(31 \%)$ \\
\hline
\end{tabular}

